\title{
IL12B wt Allele
}

National Cancer Institute

\section{Source}

National Cancer Institute. IL12B wt Allele. NCI Thesaurus. Code C52043.

Human IL12B wild-type allele is located within 5q31.1-q33.1 and is approximately $16 \mathrm{~kb}$ in length. This allele, which encodes interleukin-12 beta chain protein, plays a role in promoting the growth of both T cells and natural killer cells. It is also involved in the differentiation of both Th1 and Th2 cells. Overexpression of the IL12B gene is associated with multiple sclerosis. A polymorphism in the promoter region of this gene is associated with the severity of both atopic and non-atopic asthma in children. Heritable defects in the IL12B gene are a cause of susceptibility to mycobacterial disease. 